\title{
Phosphorus Reduction Through Precision Feeding of Dairy Cattle
}

\author{
P. E. Cerosaletti, ${ }^{1}$ D. G. Fox ${ }^{2}$ and L. E. Chase ${ }^{2}$ \\ ${ }^{1}$ Cornell Cooperative Extension of Delaware County, Hamden, NY 13782 \\ ${ }^{2}$ Department of Animal Science, Cornell University, Ithaca, NY 14853
}

\section{ABSTRACT}

A study was conducted on 4 dairy farms in the Cannonsville Reservoir Basin (Delaware County, NY) to identify feeding strategies in commercial dairy herds that will reduce manure phosphorus and mass farm phosphorus balance. Lactating cow diets on all 4 farms were evaluated monthly for 28 mo using the Cornell Net Carbohydrate and Protein System. Milk production and herd reproductive performance were measured monthly. Manure phosphorus content was measured every 6 mo. Reduced phosphorus diets (precision feeding) were implemented in 2 of the herds. Mean herd phosphorus intakes in the 4 herds ranged from 107 to $165 \%$ of requirement. Dietary phosphorus intakes in the 2 herds where diets were modified were reduced from $153 \%$ of requirement to $111 \%$, an average reduction of $25 \%$. Predicted phosphorus intakes and manure excretions were reduced $11.8 \mathrm{~kg} / \mathrm{yr}$ per cow. After dietary adjustments in the 2 herds, fecal phosphorus concentrations decreased $33 \%$. Milk production was not adversely affected by reduced phosphorus diets. Whole farm mass phosphorus balances (amount of phosphorus remaining on the farm) on the 2 farms were reduced $49 \%$, with the percentage of imported phosphorus remaining on the farm reduced to less than $45 \%$. Achieving feed phosphorus reductions similar to those of this study on all of the estimated 7000 to 8000 mature dairy cattle in the Cannonsville Basin could reduce feed phosphorus imports and manure phosphorus excretions more than $64,000 \mathrm{~kg} / \mathrm{yr}$. This would slow the rate of phosphorus accumulation in agricultural soils in the Cannonsville Basin, which over time could reduce the $50,000 \mathrm{~kg} / \mathrm{yr}$ average total phosphorus loading of the Cannonsville Reservoir.

(Key words: phosphorus, precision feeding, nutrient management)

Abbreviation key: ADICP = acid detergent insoluble crude protein, $\mathbf{C N C P S}=$ Cornell Net Carbohydrate and Protein System, NDICP = neutral detergent insoluble crude protein.

Received August 8, 2003.

Accepted January 19, 2004.

Corresponding author: P. E. Cerosaletti; e-mail: pec6@cornell.edu.

\section{INTRODUCTION}

Increasing emphasis is being placed on $\mathrm{P}$ as a pollutant in US surface water sources. Phosphorus has been identified as a major pollutant of concern in the Cannonsville Reservoir Basin, the third largest source of water for New York City, due to its impact on water quality and the subsequent economic challenges of addressing P issues (Delaware County Watershed Affairs, 2002). Agriculture accounts for $70 \%$ of the annual nonpoint source total P load entering the Cannonsville Reservoir (Longabucco and Rafferty, 1998; Longabucco, 2001). Dairy farming accounts for most of agricultural activity in the Cannonsville Reservoir Basin, and these farms grow all forages and purchase (import) all concentrate feeds. These farms are typical of dairy farms in New York state, with more $P$ entering dairy farms than is exported in milk, meat, or crops sold, thus resulting in a net annual accumulation of $\mathrm{P}$ on the farm ranging from 19 to $41 \mathrm{~kg} / \mathrm{cow}$ (Klausner, 1993; Klausner et al., 1998). Purchased feed has been identified as the single largest source of imported $\mathrm{P}$ on dairy farms, accounting for 65 to $85 \%$ of the 28 to $51 \mathrm{~kg}$ of $\mathrm{P}$ imported annually per cow reported for typical commercial dairy farms in New York (Tylutki and Fox, 1997; Cerosaletti et al., 1998; Klausner et al., 1998). Similar percentages have been reported for dairy farms in The Netherlands (Valk et al., 2000) and Pennsylvania (Bacon et al., 1990). The majority of the $\mathrm{P}$ in typical dairy diets is excreted in the feces (Morse et al., 1992). In the northeastern United States, this manure P is then applied to cropland as a fertilizer for crop production, with a portion of it then being incorporated into the crop.

Recent research indicates that dietary $\mathrm{P}$ management will be a key strategy in reducing $\mathrm{P}$ imports and accumulation on dairy farms (Kuipers et al., 1999; Valk et al., 2000; Powell et al., 2001). The Phosphorus Reduction Through Precision Animal Feeding Program was developed and implemented in the Cannonsville Reservoir Basin in Delaware County with the objectives of investigating and implementing strategies to reduce $\mathrm{P}$ accumulation on dairy farms. The objective of this study was to determine the excess $\mathrm{P}$ being fed on a sample of dairy farms in the Cannonsville Basin and to identify and evaluate dietary strategies that will reduce purchased feed $\mathrm{P}$ imports and $\mathrm{P}$ in manure. 


\section{MATERIALS AND METHODS}

This study was conducted on 4 dairy farms in the Cannonsville Reservoir Basin; their herd sizes were $78,45,65$, and 100 adult cows (herds A, B, C, and $\mathrm{D}$, respectively). The herds were selected because they were representative of herds typical of the Cannonsville Basin and were willing to participate in the study. Herds A and B are tie-stall-barn, component-fed herds, with all feeds, including purchased concentrates, being fed separately to each individual cow. Herds C and D are tie-stall-barn herds fed TMR, with small amounts of hay and purchased grain top-dressed separately to individual cows. Lactating cow diets, forage quality, cow performance, and manure nutrient composition were monitored for 28 mo on all 4 farms, beginning in December 1999. Feed intake, feed quality, and production data were collected at monthly intervals in conjunction with production test day. Data collected daily included temperature, humidity, and daily bulk-tank, mean herd milk production per cow. All lactating cows in each herd were scored for body condition every 3 mo during the study, using the method of Edmonson et al. (1989). Individual cow fecal samples were obtained on each farm to determine fecal $\mathrm{P}$ content. Every $6 \mathrm{mo}$, beginning in December 1999, 9 cows were sampled on each farm. Three cows were selected randomly from 3 DIM groupings within the herds: $<120$ DIM, 120 to 240 DIM, and $>240$ DIM. All samples were taken via rectal palpation, to avoid contamination with bedding, urine, and feces from adjacent cows. These samples were analyzed for P content at the DairyOne Forage Laboratory (DairyOne; Ithaca, NY) using the ICP atomic emission spectrometry method of Sirois et al. (1994). Feed samples (forages and grain mixes) were analyzed at DairyOne for DM, NDF, lignin, CP, crude fat, ash, soluble protein, neutral detergent insoluble crude protein (NDICP), acid detergent insoluble crude protein (ADICP), Ca, P, and K. With forages, all components were analyzed by near infrared reflectance spectroscopy, except for minerals (analyzed by ICP spectrometry), lignin (analyzed by ANKOM A200 filter bag technique, 3$\mathrm{h} 72 \% \mathrm{wt} / \mathrm{wt}$ sulfuric acid incubation; ANKOM Technology Corp., Macedon, NY), NDICP (analyzed by Kjeldahl or Kjeltec analysis of NDF residue), and ADICP (analyzed by Kjeldahl or Kjeltec analysis of ADF residue). For grain mixes, samples were analyzed with the procedure above except for CP (Kjeldahl procedure with a boric acid receiving solution), soluble protein (using a sodium borate-sodium phosphate buffer procedure), ADF, and NDF (ANKOM A200 filter bag technique).

Production test day data were collected, sorted, and summarized using Dairy Comp 305 (Valley Agricultural Software, Tulare, CA). Herd data were sorted for each month into 4 production groups within the herds: $<23,23$ to 32,32 to 41 , and $>41 \mathrm{~kg} / \mathrm{d}$ per cow. Lactating cow diets were modeled and $\mathrm{P}$ intakes and excretions were predicted using the Cornell Net Carbohydrate and Protein System (CNCPS) version 4.0 (Fox et al., 2000) for each production group. Once rations were modeled across production groups, strategies were developed for herds $\mathrm{A}$ and $\mathrm{B}$ to reduce $\mathrm{P}$ intakes as close to requirement as possible by manipulating purchased feed $\mathrm{P}$ sources. Herds A and B were selected for dietary intervention based primarily on their willingness and capability to implement dietary changes. Their selection for implementation was made prior to determining baseline $\mathrm{P}$ intakes. Had there been no overfeeding of $\mathrm{P}$ in herd A or B baseline diets (which was not the case), another herd would have been selected. Forage intake levels in these herds were not controlled; the intent was to examine strategies that could be implemented through the purchased feed portion of the diet. Dietary strategies were developed by the project specialist in close cooperation with the farm owners and their feed industry representatives. Intervention strategies were implemented from November 2000 through January 2001, and changes in nutrient intakes and excretions, feed costs, milk production, and reproductive performance were monitored. Milk production was monitored short-term before and after implementation of dietary changes on the basis of daily milk sold per cow. Longterm milk production trends were monitored as monthly herd average milk production per cow, with the data standardized to $150 \mathrm{DIM}$ and $4 \%$ FCM to control for stage of lactation and energy content variability. In herds $\mathrm{C}$ and $\mathrm{D}$, monthly monitoring continued for the duration of the study without dietary intervention.

Whole-farm nutrient import and export data were collected for herds A and B for the years 2000 (preimplementation) and 2001 (postimplementation) to compute whole-farm mass nutrient balances for $\mathrm{N}, \mathrm{P}$, and $\mathrm{K}$. These data were summarized for the pre- and postimplementation periods using the procedure of Klausner et al. (1997) to calculate whole-farm mass nutrient balances, where the whole-farm mass balance is equal to the difference between farm nutrient imports (concentrates, crops, bedding, animals, fertilizer, and, in the case of $\mathrm{N}$, symbiotic fixation by legumes) and farm nutrient exports (milk, animals, and crops). Nutrient import and export amounts were determined from farm records. In the case of crops and bedding, nutrient content values were determined via analysis. Nutrient content values suggested by Klausner et al. (1997) were used for animals (mature cows, percentage of live weight, $2.53 \% \mathrm{~N}, 0.72 \% \mathrm{P}, 0.19 \% \mathrm{~K}$; calves and heifers, percentage of live weight, $2.88 \% \mathrm{~N}, 0.83 \% \mathrm{P}, 0.22 \% \mathrm{~K}$ ) and milk (as-sampled basis, $0.56 \% \mathrm{~N}, 0.10 \% \mathrm{P}, 0.15 \%$ 
K). Nitrogen fixation was determined using the equation of Klausner et al. (1997):

number of acres of legume or grass-legume mix $\times \mathrm{DM}$ yield/acre $\times$ legume factor $\times(\% \mathrm{CP} / 100) \times$ fixation factor $\times 0.16$

where fixation factor was a constant set equal to 0.60 , and legume factor was set equal to 1.0 for crop acres of $\geq 90 \%$ legume and 0.60 for crop acres of $<90 \%$ legume. Crop yields were determined from farm records and percentage of $\mathrm{CP}$ was determined from forage analysis. An adjusted whole-farm mass balance was calculated for both herds for the postimplementation year, primarily to account for atypical crop purchases on both farms in the postimplementation year due to pest-induced crop loss, but also to remove variation in mass balance between years within herd from other sources, except for purchased concentrate feed. The adjusted mass balance was calculated by setting all nutrient imports and exports in the postimplementation year equal to those in the preimplementation year, except for purchased concentrate amounts and N, P, and K densities, which were adjusted to actual postimplementation purchased concentrate feeding rates per cow and $\mathrm{N}, \mathrm{P}$, and $\mathrm{K}$ densities.

\section{STATISTICAL ANALYSIS}

Body condition score data for individual cows were pooled into pre- and postimplementation periods for herds $\mathrm{A}$ and $\mathrm{B}$, and means were tested for differences using a 2 -sample $t$-test for 2 means assuming unequal variance. Individual cow manure $\mathrm{P}$ content data were pooled by implementation (herds A and B) and nonimplementation (herds C and D) and by means for preand post-implementation time periods. Means were tested for difference using a 2 -sample $t$-test for 2 means assuming unequal variance. Reproductive performance data were summarized using Dairy Comp 305, isolating performance for pre- and postimplementation periods in herds A and B. Reproductive data from cows denoted "not to be bred" in Dairy Comp 305 were not included in summaries. Daily and monthly milk production data for herds A and B were summarized for pre- and postimplementation periods, but were not subject to further statistical analysis as there were several variables affecting milk production that were not controlled for.

\section{RESULTS AND DISCUSSION}

Prior to any dietary adjustments, $\mathrm{P}$ intakes exceeded $\mathrm{P}$ requirements across all herds by $32 \%$ (Table 1 ). This excess is greater than the mean of $21 \%$ overfeeding
Table 1. Phosphorus intake as a percentage of requirement for project herds prior to dietary adjustment.

\begin{tabular}{llllrl}
\hline & \multicolumn{5}{c}{ Milk production level, kg/d per cow } \\
\cline { 2 - 6 } Item & $<23$ & $23-32$ & $32-41$ & $>41$ & Mean \\
\hline Herd A & 154 & 171 & 174 & 161 & 165 \\
Herd B & 145 & 149 & 140 & 130 & 141 \\
Herd C & 116 & 108 & 106 & 99 & 107 \\
Herd D & 133 & 115 & 107 & 101 & 114 \\
\hline
\end{tabular}

reported by Bertrand et al. (1999) for 27 commercial dairy farms in South Carolina, but nearly identical to the average $30 \%$ overfeeding reported by Sansinena et al. (1999) in a survey of dairy nutritionists working in the midsouthern United States. Bertrand et al. (1999) reported a range of 76 to $213 \% \mathrm{P}$ in intakes as a percentage of requirement, far larger than the range seen on the four farms in this study. Within herds B, C, and D, $\mathrm{P}$ intakes as a percentage of requirement, while still in excess, declined with increasing milk production level. This trend agrees with the dietary modeling of Chase (1998) and is due to higher-producing cows having a greater $\mathrm{P}$ requirement relative to DMI compared with lower producing cows. In herd A, no consistent trend in $\mathrm{P}$ intake across production level was detected.

In herd A, even though dietary $\mathrm{P}$ intakes were well in excess of requirement, limited amounts of mineral $\mathrm{P}$ were fed, even before dietary adjustments were made. Most of the dietary $\mathrm{P}$ in this herd was from forages (Table 2) and from by-product feeds used in the grain mix, in particular wheat middlings (Table 3). This feed was used heavily in this pelleted grain mixture not only to reduce feed cost, but also to obtain a good-quality pellet. Herd B, like herd A, had high forage P levels (Table 2). Additionally, this herd was fed a greater level of mineral $\mathrm{P}$ in the purchased concentrate (Table 3), as well as high-P concentrate feeds (distillers' grains, whole roasted soybeans). The lower $\mathrm{P}$ intakes in herd $\mathrm{C}$ may be attributable to the use of a low $\mathrm{P}(8.73 \% \mathrm{P})$ liquid mineral source included in the TMR at a low rate (1.2 dl/d per cow; data not shown). Use of a mineral supplement of this type is not common on most northeastern US dairy farms. Lower P intakes in herd D may be attributable to the use of a low-P mineral mixture $(4.6 \% \mathrm{P})$ included in the diet at a low rate $(318 \mathrm{~g} /$ d per cow). Furthermore, this herd had the highest inclusion rate of corn silage of any of the herds in this study (data not shown), a strategy that has been shown to reduce ration $\mathrm{P}$ content (Alocilja, 1998). Across all herds in the study, corn silage had the lowest mean $\mathrm{P}$ content of all forages fed (Table 2).

The forage $\mathrm{P}$ levels for the project herds summarized in Table 2 represent 2 growing seasons. The DairyOne averages included in this table are largely from north- 
Table 2. Mean, SD, and CV of forage $P$ contents for all project herds and similar forages analyzed at the DairyOne Forage Laboratory.

\begin{tabular}{|c|c|c|c|c|c|}
\hline & $\begin{array}{l}\text { Mean } \\
\% \text { of DM }\end{array}$ & SD & $\mathrm{CV}, \%$ & $\mathrm{n}$ & $\begin{array}{l}\text { Samples } \\
\geq 0.40 \% \\
\text { DM, \% }\end{array}$ \\
\hline \multicolumn{6}{|l|}{ Herd A } \\
\hline Grass and $\mathrm{MMG}^{1}$ & 0.38 & 0.08 & 21 & 68 & 53 \\
\hline Legume and $\mathrm{MML}^{2}$ & - & - & - & - & - \\
\hline Corn silage & 0.27 & 0.06 & 22 & 22 & 0 \\
\hline \multicolumn{6}{|l|}{ Herd B } \\
\hline Grass and MMG & 0.40 & 0.10 & 25 & 55 & 40 \\
\hline Legume and MML & 0.39 & 0.07 & 18 & 28 & 39 \\
\hline Corn silage & - & - & - & - & - \\
\hline \multicolumn{6}{|l|}{ Herd C } \\
\hline Grass and MMG & 0.39 & 0.05 & 13 & 12 & 50 \\
\hline Legume and MML & 0.38 & 0.05 & 13 & 44 & 45 \\
\hline Corn silage & 0.25 & 0.04 & 16 & 12 & 0 \\
\hline \multicolumn{6}{|l|}{ Herd D } \\
\hline Grass and MMG & 0.40 & 0.09 & 23 & 28 & 61 \\
\hline Legume and MML & 0.37 & 0.05 & 14 & 26 & 38 \\
\hline \multirow{2}{*}{\multicolumn{6}{|c|}{ DairyOne Laboratory ${ }^{3}$}} \\
\hline & & & & & \\
\hline Legume hay & 0.26 & 0.06 & 23 & & \\
\hline Legume silage & 0.32 & 0.06 & 19 & & \\
\hline Grass hay & 0.24 & 0.08 & 33 & & \\
\hline Grass silage & 0.31 & 0.07 & 23 & & \\
\hline Corn silage & 0.23 & 0.03 & 13 & & \\
\hline
\end{tabular}

${ }^{1} \mathrm{MMG}=$ Mixed mainly grass.

${ }^{2} \mathrm{MML}=$ Mixed mainly legumes.

${ }^{3}$ Chase, 1999.

eastern US dairy farms, predominantly those in New York. Higher mean forage P levels for forages analyzed in this project compared with the DairyOne data may be attributable to higher soil $\mathrm{P}$ levels on the project farms or a difference in soil mineralogy, resulting in plants containing a higher $\mathrm{P}$ level. Forage $\mathrm{P}$ levels for forages in this study may also differ from those analyzed at DairyOne due to plant maturity. In general, mineral content decreases as forage maturity increases as a result of changing leaf:stem ratios, varying mineral content of plant organs, and increased fiber content (Fleming, 1973; Little, 1982). Variation in P content in project herds is similar to that reported for the DairyOne forages.

The higher forage $\mathrm{P}$ levels observed in the project herds are of biological importance in balancing diets from a nutrient management perspective. These results point to the importance of analyzing forages accurately for nutrient content in balancing dairy rations. In this study, relying on average tabular values for forage $\mathrm{P}$ content would have resulted in an underestimation of forage $\mathrm{P}$ content and an oversupplementation of ration $\mathrm{P}$. Higher forage $\mathrm{P}$ content provides an opportunity to reduce supplemental (imported) ration $\mathrm{P}$. In some instances, as is presently the case in herds $\mathrm{A}$ and $\mathrm{B}, \mathrm{P}$ supplied by forages and grains alone (with no mineral $\mathrm{P}$ ) may meet or exceed animal $\mathrm{P}$ requirements. In these cases, further reductions in $\mathrm{P}$ imports will need to come from reductions in the amount of purchased concentrate fed.

From an agronomic perspective, higher forage $\mathrm{P}$ content represents an opportunity to remove more soil $\mathrm{P}$ in herbage biomass, which is important in P-based nutrient management planning, where manure spreading rates may be limited to crop $\mathrm{P}$ removal. Higher forage $P$ removal rates could, over a long time period, result in a slower rate of soil $\mathrm{P}$ accumulation, or even a decline in soil P. Additionally, homegrown forage $\mathrm{P}$ represents a recycling of $\mathrm{P}$ within the farm and the opportunity to export $\mathrm{P}$ in the form of milk every time the $\mathrm{P}$ cycle is turned.

Composition, cost, and $\mathrm{CP}$ and $\mathrm{P}$ densities of the grain mixtures fed in herds A and B before and after dietary adjustments appear in Table 3 and indicate the changes needed in both herds to lower $\mathrm{P}$ intakes. To reduce $\mathrm{P}$ intake in herd $\mathrm{A}$, an unpelleted grain mixture was developed that allowed for a reduced level of wheat middlings. To compensate for increased feed costs as a result of replacing wheat middlings with more expensive ingredients, a 2-feed system was implemented in this herd, with nearly equal amounts of a higher protein concentrate and cornmeal being fed as separate feeds. This reduced feed mixing costs and took advantage of economic benefits of concentrating nutrients in the higher protein feed. Additionally, total concentrate levels were reduced to bring the diets into protein and energy balance (Table 4). These changes resulted in a slightly decreased energy intake as well as decreased purchased feed costs of approximately $\$ 0.20 / \mathrm{d}$ or $\$ 6.00 /$ mo per cow.

Dietary $\mathrm{P}$ intakes in herd A were still in excess of requirement after implementation of reduced-P diets (Table 5), due largely to high P levels in the forages fed to this herd (Table 2). Many of the forages in herd A contained $\mathrm{P}$ levels that were higher than the NRC (2001) recommended total dietary P levels for cows at similar levels of milk production and DMI. Additional $P$ reductions might have been achieved by replacing more wheat middlings in the protein mixture with a lower P feed, such as corn meal or citrus pulp. This was not done for cost and palatability reasons.

In herd B, the only dietary adjustments made were to remove mineral $\mathrm{P}$ sources and reformulate the mineral component of the complete grain mixture (Table 3). One of these mineral sources was a mineral premix, which, when removed, had to be replaced with another mineral premix and several individual mineral ingredients to maintain levels for all other minerals and vitamins. Due to the pricing structure of the mineral premixes and other mineral ingredients, there was only a slight decrease in purchased feed cost $(\$ 3.00 / t$ of mixed grain; 
Table 3. Composition of high and low $\mathrm{P}$ grain mixes for herds A and B.

\begin{tabular}{|c|c|c|c|c|}
\hline \multirow[b]{3}{*}{ Ingredient } & \multicolumn{4}{|c|}{ Composition of complete feed mix, $\%$ as sampled } \\
\hline & \multicolumn{2}{|c|}{ Herd A } & \multicolumn{2}{|c|}{ Herd B } \\
\hline & High-P mix & Low-P mix & High-P mix & Low-P mix \\
\hline Wheat middlings & 44.15 & 22.50 & & \\
\hline Corn meal & 18.00 & 0.00 & 44.83 & 44.75 \\
\hline Crimped corn & 0.00 & 7.50 & & \\
\hline Distillers' grains, dehydrated & 5.00 & 7.50 & 12.50 & 12.50 \\
\hline Soybean oil meal, $47.5 \%$ & 18.75 & 34.00 & & \\
\hline Soybeans, whole roasted & & & 11.25 & 11.25 \\
\hline Cottonseed meal pellet & & & 7.50 & 7.50 \\
\hline Citrus pulp & 0.00 & 10.00 & & \\
\hline Molasses & 3.00 & 5.00 & 8.75 & 8.75 \\
\hline Crimped barley & & & 5.00 & 5.00 \\
\hline Gluten feed & 2.25 & 0.00 & & \\
\hline Linseed meal & & & 2.50 & 2.50 \\
\hline Urea & 0.75 & 0.50 & & \\
\hline Tallow & 0.75 & 0.75 & & \\
\hline Rumen bypass fat & & & 0.50 & 0.50 \\
\hline Sodium bicarbonate & 1.25 & 2.00 & 1.00 & 1.00 \\
\hline Calcium sulfate & 0.00 & 1.50 & & \\
\hline Magnesium oxide & 0.25 & 0.60 & 0.29 & 0.40 \\
\hline Sodium selenite, $0.06 \%$ & & & 0.08 & 0.08 \\
\hline Sodium selenite, $0.02 \%$ & 0.10 & 0.45 & & \\
\hline Dicalcium phosphate & 0.25 & 0.00 & 0.49 & 0.00 \\
\hline Mineral premix $\mathrm{A}^{1}$ & & & 3.60 & 0.00 \\
\hline Mineral premix $\mathrm{B}^{2}$ & & & 0.12 & 0.67 \\
\hline Mineral premix $\mathrm{C}^{3}$ & 0.30 & 0.60 & & \\
\hline Salt & 1.00 & 2.00 & 0.00 & 1.00 \\
\hline Limestone & 2.75 & 3.50 & 0.00 & 2.50 \\
\hline Vitamins A, D, E premix & & & 0.05 & 0.05 \\
\hline Vitamin E & 0.10 & 0.25 & 0.05 & 0.05 \\
\hline Binder & 0.75 & 0.75 & 1.00 & 1.00 \\
\hline Yeast culture & 0.60 & 0.60 & 0.49 & 0.50 \\
\hline Total & 100 & 100 & 100 & 100 \\
\hline Change in cost, $\% / t^{4}$ & - & +17 & - & -2 \\
\hline Crude protein content, \% DM & 24.40 & 27.40 & 17.34 & 17.24 \\
\hline Phosphorus content, \% DM & 0.94 & 0.69 & 0.62 & 0.43 \\
\hline
\end{tabular}

$\$ 0.02 / \mathrm{d}$ per cow). Level of concentrate fed in the diet was not changed. These changes alone were enough to lower $\mathrm{P}$ intake to required levels (100\% of requirement; Table 5). As with herd A, herd B diets had large P contributions from homegrown forage, with mean forage $\mathrm{P}$ density exceeding $\mathrm{NRC}$ (2001) recommended minimum total dietary $\mathrm{P}$ density for cows at similar levels of milk production and DMI. With no corn silage fed to herd $\mathrm{B}$, there were limited amounts of low-P forage to dilute the higher-P forages. Similar challenges have been reported regarding $\mathrm{P}$ content of the grass forages in the Netherlands (Valk et al., 2000).

By implementing P-reducing strategies in the diets of herds $\mathrm{A}$ and $\mathrm{B}$, predicted $\mathrm{P}$ intakes and excretions were reduced by an average of 25 and $33 \%$, respectively, across both herds (Table 5). Absolute $\mathrm{P}$ reductions averaged 40 and $25 \mathrm{~g} / \mathrm{d}$ per cow (14.6 and $9.1 \mathrm{~kg} / \mathrm{yr}$ per cow) for herds A and B, respectively. Within herds, these reductions increased with increasing production level, a result of the greater total daily $\mathrm{P}$ intake of higherproducing cattle. When $\mathrm{P}$ reductions are expressed as a percentage of $\mathrm{P}$ intakes and excretions, a similar trend holds for herd A, but is less consistent for herd B. Measured fecal $\mathrm{P}$ concentration decreased significantly (1.32\% of DM before implementation vs. $0.88 \%$ after implementation, $P<0.001, \mathrm{n}=90$ ), by an average $33 \%$ across herds $\mathrm{A}$ and $\mathrm{B}$, whereas mean fecal $\mathrm{P}$ content of the nonimplementation herds did not decrease during the same period $(0.96$ vs. $0.92 \%$ of DM, $P=0.22, \mathrm{n}=$ 90). These reductions in $P$ intake are somewhat greater than those reported by Valk et al. (2000) when P-reduced diets were fed on Dutch dairies (3 to $6 \mathrm{~kg} / \mathrm{yr}$ per cow); however, these dairies started with lower concentrate $\mathrm{P}$ levels than those in the present study. 
Table 4. Diet for herd A for January 2001 test $^{1}$ before and after dietary adjustments; herd average production of $32.7 \mathrm{~kg} / \mathrm{d}$ per cow.

\begin{tabular}{|c|c|c|}
\hline Item & High-P diet & Low-P diet \\
\hline & \multicolumn{2}{|c|}{$\longrightarrow \mathrm{kg}$ of $\mathrm{DM} / \mathrm{d}$} \\
\hline 1st cut grass round bale silage & 3.8 & 3.8 \\
\hline 3rd cut grass round bale silage & 1.6 & 1.6 \\
\hline 2nd cut grass hay & 3.3 & 3.3 \\
\hline Corn silage & 2.9 & 2.9 \\
\hline Corn meal & 2.4 & 4.0 \\
\hline High $\mathrm{P}$ grain mix & 8.1 & \\
\hline Low $\mathrm{P}$ grain mix & & 5.7 \\
\hline Total DMI & 22.1 & 21.3 \\
\hline Metabolizable energy balance, $\%$ & 106 & 103 \\
\hline Days to gain 1 condition score & 231 & 441 \\
\hline Metabolizable protein balance, \% & 102 & 101 \\
\hline Urea cost, Mcal/d & 1.11 & 0.60 \\
\hline Dietary CP density, \% & 18.3 & 17.6 \\
\hline Dietary P density, \% & 0.56 & 0.44 \\
\hline $\mathrm{P}$ intake, $\%$ of requirement & 152 & 112 \\
\hline
\end{tabular}

${ }^{1}$ Month that reduced-P diets were initiated in herd A.

Short- and long-term milk production data for both herds A and B before and after dietary adjustments (Table 6) suggest that no dramatic short-term drops in milk production have occurred as a result of reducing $\mathrm{P}$ in dairy diets. Herd A experienced a milk production increase immediately after implementing dietary changes, which may be attributable to increased intake of rumen-fermentable carbohydrate and/or metabolizable protein, although diets were not balanced to support such increases. Recent studies assessing long-term lactation performance have reported no reduction in milk yield with lactating dairy cattle fed at required or slightly lower than required P levels (Kuipers et al., 1999; Valk et al., 1999; Wu and Satter, 2000; Wu et al., 2000).

The measures of BCS and reproductive performance for herds A and B (Table 7) need to be interpreted with caution, as this study was not controlled for the many variables that can influence reproductive performance. Herd A experienced a slight decrease in BCS after im- plementation, which could be attributable to reduced metabolizable energy values in reduced-P diets (106 vs. $103 \%$ of requirement; Table 4). Heat detection, conception, and pregnancy rates were all lower (worse) after implementation for this herd, although the percentage of cows open (not pregnant) greater than 150 DIM improved (decreased). These changes in reproductive performance are small and may be due to normal variation. If reproductive performance was decreased in this herd postimplementation, it may have been due to reduced energy intake and greater BCS loss (greater negative energy balance), as evidenced by lower BCS in the postimplementation period. Although negative energy balance, especially in early lactation, has been reported to adversely affect fertility (Butler and Smith, 1989; Swanson, 1989), reported relationships between BCS and reproductive performance have not been consistent. Pryce et al. (2001) demonstrated that reproductive performance is negatively correlated with BCS loss in lactating dairy cows, whereas Waltner et al. (1993) and Ruegg and Milton (1995) found no such relationships. Herd B experienced an increase in BCS and all reproductive measurements showed improvement postimplementation. Changes in BCS in both herds were not large. With regard to the effect of $\mathrm{P}$ intake on reproductive performance, the data in herd B of this study are consistent with those of other studies (Wu and Satter, 2000; Wu et al., 2000, 2001), which indicate no improvement in reproductive performance when feeding $\mathrm{P}$ above NRC (2001) recommended levels. Several studies (Valk and Sebek, 1999; Wu and Satter, 2000; Wu et al., 2000) found no impairment in reproductive performance when feeding $\mathrm{P}$ below NRC requirement, even at levels as low as $0.30 \%$ of diet DM.

Whole-farm mass nutrient balances were determined for both pre- and postimplementation years for herds A and B (Table 8). Initial nutrient balances are consistent with those reported for typical northeastern US commercial dairy farms (Tylutki and Fox, 1997; Cerosaletti

Table 5. Predicted reductions in $\mathrm{P}$ intakes and manure $\mathrm{P}$ excretions after implementing $\mathrm{P}$ reduced diets in herds $\mathrm{A}$ and $\mathrm{B}$.

\begin{tabular}{|c|c|c|c|c|c|}
\hline \multirow[b]{2}{*}{ Item } & \multicolumn{5}{|c|}{ Milk production level, kg/d per cow } \\
\hline & $<23$ & $23-32$ & $32-41$ & $>41$ & Average \\
\hline \multicolumn{6}{|l|}{ Herd A } \\
\hline $\mathrm{P}$ intake, $\%$ of requirement & 125 & 121 & 118 & 108 & 118 \\
\hline Reduction, g/d & 16 & 37 & 50 & 57 & 40 \\
\hline Reduction, \% of intake & 18 & 29 & 32 & 33 & 28 \\
\hline Reduction, \% of excretion & 22 & 36 & 40 & 44 & 36 \\
\hline \multicolumn{6}{|l|}{ Herd B } \\
\hline $\mathrm{P}$ intake, $\%$ of requirement & 100 & 109 & 100 & 101 & 103 \\
\hline Reduction, g/d & 19 & 21 & 31 & 27 & 25 \\
\hline Reduction, $\%$ of intake & 22 & 20 & 24 & 19 & 21 \\
\hline Reduction, \% of excretion & 27 & 30 & 33 & 27 & 29 \\
\hline
\end{tabular}


Table 6. Short and long term milk production for herds A and B before and after implementation of reduced $\mathrm{P}$ diets.

\begin{tabular}{|c|c|c|c|c|}
\hline \multirow[b]{2}{*}{ Item } & \multicolumn{2}{|c|}{ Mean daily herd milk weights ${ }^{1}$} & \multicolumn{2}{|c|}{ Mean monthly milk weights ${ }^{2}$} \\
\hline & Before & After & Before & After \\
\hline \multicolumn{5}{|l|}{ Herd A } \\
\hline No. of observations & 10 & 10 & 14 & 14 \\
\hline Milk, kg/d per cow & 28.6 & 30.4 & 31.8 & 32.2 \\
\hline \multicolumn{5}{|l|}{ Herd B } \\
\hline No. of observations & 10 & 10 & 13 & 15 \\
\hline Milk, kg/d per cow & 34.9 & 34.5 & 33.1 & 35.4 \\
\hline
\end{tabular}

${ }^{1}$ Mean weights for $10 \mathrm{~d}$ immediately pre- and postimplementation.

${ }^{2}$ Standardized to 150 DIM, 4\% FCM.

et al., 1998; Klausner et al., 1998), as well as for dairy farms in The Netherlands (Valk et al., 2000). Through dietary manipulation of concentrate $\mathrm{P}$ sources alone, the amount of $\mathrm{P}$ remaining on the farms was reduced to $49 \%$ in the adjusted balances, with reductions of 65 and $32 \%$ in the amount of $\mathrm{P}$ remaining on the farms for herds $\mathrm{A}$ and $\mathrm{B}$, respectively. The percentage of $\mathrm{P}$ remaining on both farms was reduced to less than $45 \%$. These results are less than the $78 \%$ reduction in $\mathrm{P}$ remaining/ha predicted in the modeling study of Rotz et al. (2001) for a 100-cow New York dairy farm implementing reduced dietary $P$ supplementation, where initial dietary $\mathrm{P}$ level was described as "somewhat higher than NRC (1989) requirements" and dietary P was reduced to NRC (2001) requirements. A smaller reduction in mass farm $\mathrm{P}$ balance (16\%) was obtained on a UK research farm, where feed $\mathrm{P}$ imports were reduced $32 \%$ (Peel et al., 1997).

However, actual reductions in $\mathrm{P}$ remaining on the farm in herd B were minimal (56\% preimplementation vs. $54 \%$ postimplementation). This was the result of a large and atypical purchase (import) of forage on this farm due to crop losses from drought and pest damage. From a watershed perspective, the forage was pur-

Table 7. Herd mean BCS and reproductive performance ${ }^{1}$ for herds $\mathrm{A}$ and $\mathrm{B}$ before and after implementation of reduced $\mathrm{P}$ diets (Nov. 1999-March 2002).

\begin{tabular}{lcccccc}
\hline & \multicolumn{2}{c}{ Herd A } & & \multicolumn{2}{c}{ Herd B } \\
\cline { 2 - 3 } \cline { 6 - 7 } Item & Before & After & & Before & After \\
\hline Mean BCS & \multicolumn{2}{c}{$3.02^{\mathrm{a}}$} & $2.94^{\mathrm{b}}$ & & $2.76^{\mathrm{a}}$ & $2.83^{\mathrm{a}}$ \\
Heat detection rate, \% & 48 & 43 & & 39 & 56 \\
Conception rate, \% & 50 & 47 & & 44 & 47 \\
Pregnancy rate, \% & 23 & 20 & & 16 & 27 \\
\% cows with days open $>150^{3}$ & 29 & 27 & & 23 & 21 \\
\hline
\end{tabular}

${ }^{1}$ Does not include information from animals that were coded as "not to be bred."

${ }^{2}$ Means within herd and row with different superscripts differ $(P$ $<0.05)$.

${ }^{3}$ Percentage of all mature cows in herd that were open (not pregnant) greater than 150 DIM. chased from a neighboring farm, and as such does not represent a net regional import of nutrients into the watershed, but rather a translocation within. However, this experience points out the impact that forage sources of imported nutrients can have in affecting the farm mass balance. This experience also suggests that care must be taken to assess whole-farm mass nutrient balances over several years to provide data from representative, not extreme, years. This will be especially important if US dairy farms are ever subjected to regulation based on whole-farm mass nutrient balance, as has been legislated in The Netherlands (Kuipers et al., 1999).

In both herds, $\mathrm{N}$ mass balances remained unchanged after dietary adjustments; however, dietary adjustments in herd A did result in a $15 \%$ reduction in $\mathrm{N}$ feed imports on a per-cow basis (data not shown), reflecting the reduced dietary $\mathrm{CP}$ levels in the adjusted diet (Table 4). Whereas both herds imported substantial amounts of $\mathrm{N}$ for application to grass hay crops, thus raising $\mathrm{N}$ balances, herd A had a greater percentage of cropland in grass and was more aggressive in $\mathrm{N}$ applications to grass hay crops. Potassium balances were reduced in herd A after implementation as a result of reduced imports of the mixed feed and increased imports of cornmeal, which had a lower K level. Herd B had a higher $\mathrm{K}$ balance than herd $\mathrm{A}$ as a result of application of $\mathrm{K}$ fertilizer to alfalfa hay crops, a practice not used in herd $\mathrm{A}$. Feed $\mathrm{K}$ imports in herd B were reduced after implementation due to reduced mineral $\mathrm{K}$ sources in the concentrate mixture.

The reductions in $\mathrm{P}$ intakes and manure $\mathrm{P}$ excretions obtained in this study have major implications for farm management. Reductions in manure $\mathrm{P}$ excretions can result in less crop acreage needed to recycle manure $\mathrm{P}$ under a P-based nutrient management plan (manure $\mathrm{P}$ application restricted to crop $\mathrm{P}$ removal). Powell et al. (2001) estimated that reducing dietary $\mathrm{P}$ density from 0.48 to $0.38 \%$ of $\mathrm{DM}$ would reduce manure $\mathrm{P}$ excretion enough to lower crop acreage required to recycle 
Table 8. Whole-farm mass nutrient balances before and after dietary adjustments for herds A and B.

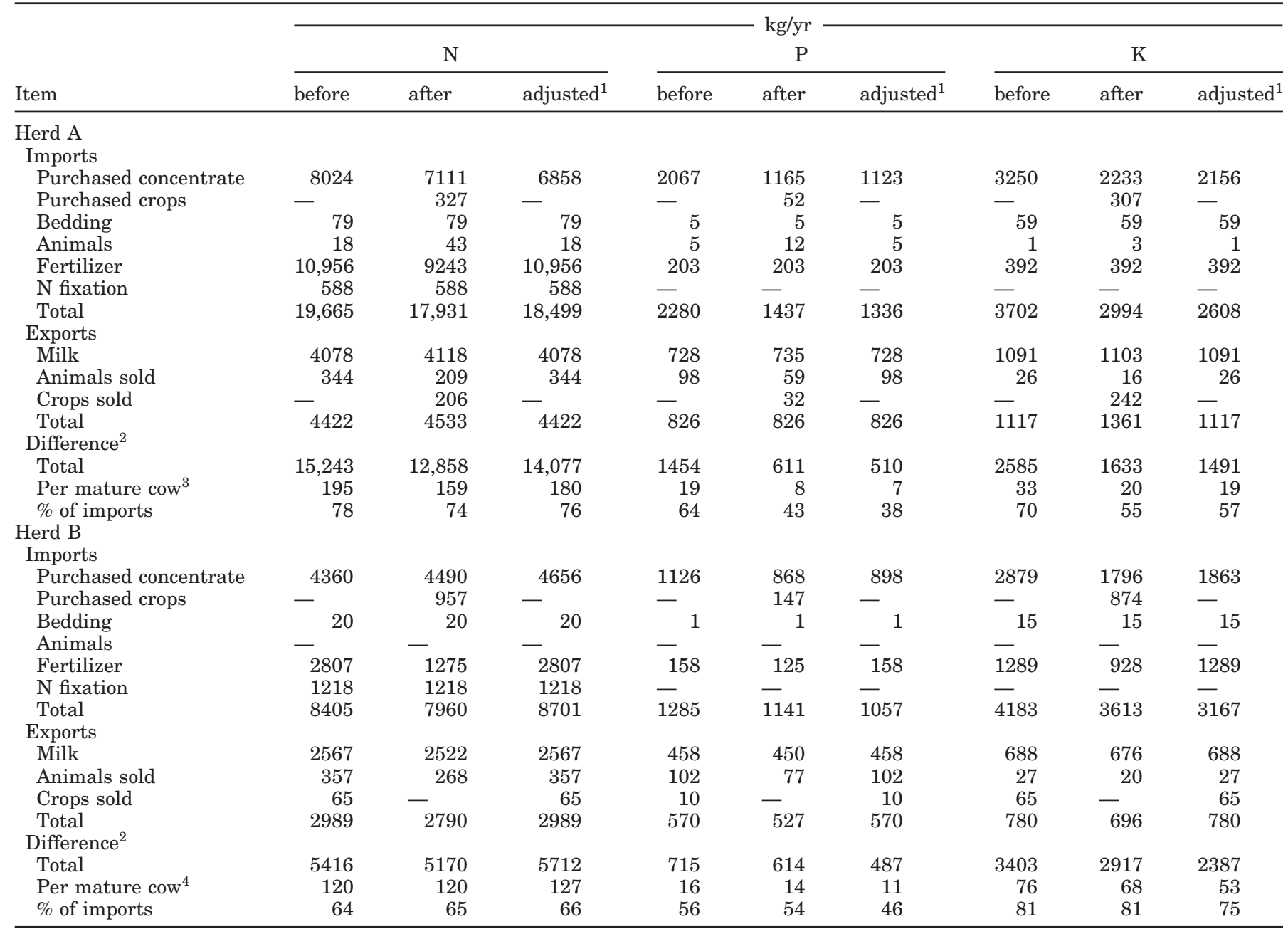

${ }^{1}$ Values in this column are the same as the "before" year with the exception of purchased concentrate amounts and N, P, and K densities, which were adjusted to "after" year purchased concentrate feeding rates per cow and N, P, and K densities.

${ }^{2}$ Amount remaining on farm.

${ }^{3}$ Number of cows, herd A: before, 78; after, 81; adjusted, 78.

${ }^{4}$ Number of cows, herd B: before, 45; after, 43; adjusted, 45.

manure $\mathrm{P}$ by $44 \%$. Crop fields that have a very high soil test $\mathrm{P}$ level resulting from excessive fertilizer and manure $\mathrm{P}$ application may also be restricted from further application of manure when nutrient management plans are designed according to USDA-NRCS (1999) guidelines. Reducing manure P content via dietary manipulation can significantly slow the rate of soil $\mathrm{P}$ accumulation, and in some cases, even bring it to equilibrium (Powell et al., 2001).

On a basin-wide scale, the $\mathrm{P}$ reductions obtained in this study have major implications. There are presently between 7000 and 8000 mature dairy cows in the Cannonsville Reservoir Basin. Should an average reduction in $\mathrm{P}$ intake and manure $\mathrm{P}$ excretion of $25 \mathrm{~g} / \mathrm{d}$ per cow be achieved across all lactating cows in the basin, then the total feed $\mathrm{P}$ imports into the basin and $\mathrm{P}$ excreted in the dairy manure produced in the basin would be reduced by 64,000 to $73,000 \mathrm{~kg} / \mathrm{yr}$. This reduction is similar to the 50,000-kg average annual total phosphorus load to the Cannonsville Reservoir (Longabucco and Rafferty, 1998; Longabucco, 2001). Reductions of this magnitude represent a substantial reduction in $\mathrm{P}$ loading on agricultural soils via manure application. Phosphorus loading (both dissolved and total $\mathrm{P}$ ) of watercourses has been shown to be highly correlated to dairy manure production and application (McFarland and Hauck, 1999). Delaware County, as part of their comprehensive strategy to manage $\mathrm{P}$ in the water bodies of the county, has set a 10,000-kg/yr goal for reducing total $\mathrm{P}$ loading to the Cannonsville Reservoir (Delaware 
County Watershed Affairs, 2002). Even if only a proportion of the manure $\mathrm{P}$ applied to the land makes it to reservoir, $\mathrm{P}$ reductions from dietary manipulation could make a substantial contribution toward that goal.

\section{CONCLUSIONS}

The results of this field study indicate that large reductions in feed $\mathrm{P}$ imports, whole-farm mass $\mathrm{P}$ balance, and manure $\mathrm{P}$ excretions can be achieved through dietary manipulation on commercial dairy farms in the northeastern US. Such reductions will be highly variable from farm to farm, based on variable levels of dietary $\mathrm{P}$ intake, forage $\mathrm{P}$ content, and willingness of the farmer to adopt reduced $\mathrm{P}$ diets. Reducing dietary $\mathrm{P}$ levels closer to requirement will require frequent and accurate feed analysis, quantification of DMI, and ration management to ensure that formulated diets are mixed and delivered to the cows properly. Strategies to reduce $\mathrm{P}$ intake by manipulating purchased concentrate will need to take into consideration mineral and by-product feed $\mathrm{P}$ sources. Choice of forages may also play a role on some farms. Forages high in $\mathrm{P}$ content may make it difficult to reduce $\mathrm{P}$ intakes to requirement; however, homegrown forages must be recognized as a recycled source of $P$ on the farm, and must not contribute to a mass nutrient imbalance. Reduced $\mathrm{P}$ dietary strategies will also need to consider structural, animal, people, and economic issues. Even modest dietary $\mathrm{P}$ reductions can have a major impact on watershed-scale $\mathrm{P}$ imports in watersheds that have large agricultural land use and where dairy farming constitutes a substantial portion of the agriculture.

\section{ACKNOWLEDGMENTS}

We would like to thank the participating farmers for their cooperation in providing data and implementing changes. This publication was supported by a subcontract with Cornell University, Water Resources Institute, under a subcontract with Delaware County Board of Supervisors on behalf of the Delaware County Department of Planning, under the Prime Project Cooperation Agreement (executed April 11, 2000) with the prime sponsor, the Department of the Army, as represented by the District Engineer of the New York District, Army Corps of Engineers.

\section{REFERENCES}

Alocilja, E. C. 1998. Zero-excess manure management in dairy through optimum rations. Trans. ASAE 41:497-501.

Bacon, S. C., L. E. Lanyon, and R. M. Schlauder, Jr. 1990. Plant nutrient flow in the managed pathways of an intensive dairy farm. Agron. J. 82:755-761.
Bertrand, J. A., J. C. Fleck, and J. C. McConnell, Jr. 1999. Phosphorus intake and excretion on South Carolina dairy farms. Prof. Anim. Sci. 15:264-267.

Butler, W. R., and R. D. Smith. 1989. Interrelationships between energy balance and postpartum reproductive function in dairy cattle. J. Dairy Sci. 72:767.

Cerosaletti, P. E., D. G. Fox, L. E. Chase, A. N. Pell, and W. A. Knoblauch. 1998. Application of the Cornell Net Carbohydrate and Protein System on a pasture based dairy farm. Pages 197211 in Proc. Cornell Nutr. Conf. Feed Manuf., Rochester, NY. Cornell Univ., Ithaca, NY.

Chase, L. E. 1998. Phosphorus in dairy cattle nutrition. Pages 212 223 in Proc. Cornell Nutr. Conf. Feed Manuf., Rochester, NY. Cornell Univ., Ithaca, NY.

Chase, L. E. 1999. Animal management strategies-How will they change with environmental regulations? Pages 65-71 in Proc. Cornell Nutr. Conf. Feed Manuf., Rochester, NY. Cornell Univ., Ithaca, NY.

Delaware County Watershed Affairs. 2002. Delaware County Action Plan DCAPII for Watershed Protection and Economic Vitality. Delaware County Dept. of Watershed Affairs, Delhi, NY.

Edmonson, A. J., I. J. Lean, L. D. Weaver, T. Farver, and G. Webster. 1989. A body condition scoring chart for Holstein dairy cows. J. Dairy Sci. 72:68.

Fleming, G. A. 1973. Mineral composition of herbage. Pages 529-566 in Chemistry and Biochemistry of Herbage. G. W. Butler and R. W. Bailey, eds. Academic Press, New York, NY.

Fox, D. G., T. P. Tylutki, K. J. Czymmek, C. N. Rasmussen, and V. M. Durbal. 2000. Development and application of the Cornell University Nutrient Management Planning System. Pages 167179 in Proc. Cornell Nutr. Conf. Feed Manuf., Rochester, NY. Cornell Univ., Ithaca, NY.

Klausner, S. D. 1993. Mass nutrient balances on dairy farms. Pages 126-129 in Proc. Cornell Nutr. Conf. Feed Manuf., Rochester, NY. Cornell Univ., Ithaca, NY.

Klausner, S. D., S. Telega, and N. Leonard. 1997. Estimating a Mass Nutrient Balance. Northeast Regional Agric. Eng. Serv., Ithaca, NY.

Klausner, S. D., D. G. Fox, C. N. Rasmussen, R. E. Pitt, T. P. Tylutki, P. E. Wright, L. E. Chase, and W. C. Stone. 1998. Improving dairy farm sustainability I: An approach to animal and crop nutrient management planning. J. Prod. Agric. 11:225-233.

Kuipers, A., F. Mandersloot, and R. L. G. Zom. 1999. An approach to nutrient management on dairy farms. J. Dairy Sci. 82(Suppl. 2):84-89.

Little, D. A. 1982. Utilization of minerals. Pages 259-283 in Nutritional Limits to Animal Production from Pastures. J. B. Hacker, ed. Commonwealth Agricultural Bureaux, Farnam Royal, UK.

Longabucco, P. 2001. Overall phosphorus budget assessment: Relative source contributions. In Proc. Delaware County Action Plan Summit Mtg.: Comprehensive strategy for the phosphorus reductions to the Cannonsville basin. Delaware County Dep. of Watershed Affairs, Delhi, NY.

Longabucco, P., and M. Rafferty. 1998. Analysis of material loading to Cannonsville Reservoir: Advantages of event-based sampling. Lake Reservoir Manag. 14:197-212.

McFarland, A. M. S., and L. M. Hauck. 1999. Relating agricultural land uses to in-stream stormwater quality. J. Environ. Qual. 28:836-844.

Morse, D., H. H. Head, C. J. Wilcox, H. H. Van Horn, C. D. Hissem, and B. Harris, Jr. 1992. Effects of concentration of dietary phosphorus on amount and route of excretion. J. Dairy Sci. 75:3039-3049.

NRC. 1989. Nutrient Requirements of Dairy Cattle. 6th rev. ed. Natl. Acad. Press, Washington, DC.

NRC. 2001. Nutrient Requirements of Dairy Cattle. 7th rev. ed. Natl. Acad. Press, Washington, DC.

Peel, S., S. J. Lane, P. J. A. Withers, A. G. Chalmers, and B. J. Chambers. R. J. Mansbridge, J. A. Metcalf, S. C. Jarvis, R. Harrison, S. Ellis, and N. Moore. 1997. Profitable but sustainable dairy systems. In Grass Is Greener? Proc. Brit. Grassl. Soc. Winter Meeting 1997, Great Malvern, UK Brit. Grassl. Soc., Reading, UK. 
Powell, J. M., Z. Wu, and L. D. Satter. 2001. Dairy diet effects on phosphorus cycles of cropland. J. Soil Water Conserv. 56:22-26.

Pryce, J. E., M. P. Coffey, and G. Simm. 2001. The relationship between body condition score and reproductive performance. J. Dairy Sci. 84:1508-1515.

Rotz, C. A., A. N. Sharpely, W. J. Gburek, M. A. Sanderson, and L. D. Satter. 2001. Production and feeding strategies for phosphorus management on dairy farms in New York. ASAE Meeting Paper No. 01-2013. ASAE, St. Joseph, MI.

Ruegg, P. L., and R. L. Milton. 1995. Body condition scores of Holstein cows on Prince Edward Island, Canada: Relationships with yield reproductive performance and disease. J. Dairy Sci. 78:552-564.

Sansinena, M., L. D. Bunting, S. R. Stokes, and E. R. Jordan. 1999. A survey of trends and rationales for phosphorus recommendations among Mid-South nutritionists. Pages 51-54 in Proc. Mid-South Rumin. Nutr. Conf., Dallas, TX.

Sirois, P. K., M. J. Reuter, C. M. Laughlin, and P. J. Lockwood. 1994. A method for determining macro and micro elements in feeds and forages by inductively coupled plasma atomic emission spectrometry. Thermo Jarrell Ash "The Spectroscopist." 3(1):6-9.

Swanson, L. V. 1989. Interactions of nutrition and reproduction. J. Dairy Sci. 72:805-814.

Tylutki, T. P., and D. G. Fox. 1997. Application of the Cornell Nutrient Management Planning System: Optimizing herd nutrition. Pages 54-65 in Proc. Cornell Nutr. Conf. Feed Manuf., Rochester, NY. Cornell Univ., Ithaca, NY.
USDA-NRCS. 1999. Conservation practice standard, nutrient management. CODE 590, part 402. Nat. Res. Conserv. Serv., Washington, DC.

Valk, H., J. A. Metcalf, and P. J. A. Withers. 2000. Prospects for minimizing phosphorus excretion in ruminants by dietary manipulation. J. Environ. Qual. 29:28-36.

Valk, H., and L. B. J. Sebek. 1999. Influence of prolonged feeding of limited amounts of phosphorus on dry matter intake, milk production, reproduction and body weight of dairy cows. J. Dairy Sci. 82:2157-2163.

Valk, H., L. B. J. Sebek, A. Th Van't Klooster, and A. W. Jongbloed. 1999. Clinical effects of feeding low dietary phosphorus levels to high yielding dairy cows. Vet. Rec. 145:673-674.

Waltner, S. S., J. P. McNamara, and J. K. Hillers. 1993. Relationship of body condition score to production variables in high producing Holstein dairy cattle. J. Dairy Sci. 76:3410-3419.

$\mathrm{Wu}, \mathrm{Z}$., and L. D. Satter. 2000. Milk production and reproductive performance of dairy cows fed two concentrations of phosphorus for two years. J. Dairy Sci. 83:1052-1063.

Wu, Z., L. D. Satter, A. J. Blohowiak, R. H. Stauffacher, and J. H. Wilson. 2001. Milk production, estimated phosphorus excretion, and bone characteristics of dairy cows fed different amounts of phosphorus for three years. J. Dairy Sci. 84:1738-1748.

Wu, Z., L. D. Satter, and R. Sojo. 2000. Milk production, reproductive performance, and fecal excretion of phosphorus by dairy cows fed three amounts of phosphorus. J. Dairy Sci. 83:1028-1041. 